\section{Marinenko V., Kulynych V.}

\title{
DEVELOPMENT OF A SOLAR COLLECTOR BASED ON ALUMINUM CONSTRUCTION HEAT PIPES
}

Об’єктом дослідження є теплова ефективність сонячних колекторів на основі алюмінієвих конструкиійних теплових труб. Сонячні колектори з тепловими трубами мають конструктивно схоже виконання. На теплосприймаючій панелі закріплені теплові труби зоною випаровування, а зони конденсачї - розташовані у баку-акумуляторі. Відмінності маються тільки в конструкціях поглинальних панелей, ділянках зон конденсаиї та теплоносіях теплових труб. Одним з найбільш проблемних місць дослідження є обгрунтування та розробка нової конструкиї теплопоглинальної панелі сонячного колектора на основі теплових труб.

Проведений огляд публікацій показав, що сонячний колектор на основі алюмінієвих конструкційних теплових труб, які працюють в режимі двофазного термосифона, має теплові втрати при передачі радіаиійного теплообміну в довгохвильовому діапазоні між поглинаючою плоскою панеллю $і$ тепловою трубою. Запропоновано проект сонячного колектора з новою, поглинаючою сонячні промені, панеллю. Для проведення аналізу ефективності роботи сонячного колектора на основі алюмінієвих конструкиійних теплових труб з новою поглинальною панеллю створено два макети сонячних колекторів - з плоскою поглинальною панеллю і циліндричною поглинальною панеллю.

Методом теплофізичного експерименту досліджені моделі сонячних колекторів на основі одної алюмінієвої конструкційної теплової труби, закріпленої на алюмінієвій плоскій та алюмінієвій циліндричній поглинальних поверхнях.

Наведені результати досліджень ефективності моделей сонячних колекторів. Теплова ефективність нового сонячного колектора на основі алюмінієвої конструкційної теплової труби з циліндричною поглинальною панеллю у початковий період нагріву води до 6 \% більша ніж у сонячного колектора з плоскою поглинальною панеллю, а в кінці нагріву - до 1,5\%. Циліндрична поверхня панелі грає роль концентратора відбитої частини випромінювання і власного випромінювання панелі в районі теплової труби.

Подальші дослідження планується проводити в напрямку оптимізацї геометричних параметрів теплопоглинальних поверхонь сонячних колекторів.

ключові слова: сонячний колектор, алюмінієва конструкиійна теплова труба, алюмінієва плоска поглинальна панель, алюмінієва щиліндрична поглинальна панель.

\section{Introduction}

When creating heat and mass transfer devices using heat pipes (HP) or two-phase thermosiphons (TPT), it opens up great opportunities for solving problems in new energyefficient systems [1-3]. There are various design solutions using HP and TPT in energy saving systems [1, 4, 5]. And also in systems operating using renewable energy sources [6, 7]. HP and TPT have a good prospect for use in solar energy systems. Solar energy is a source of energy, as a step towards reducing dependence on other energy resources. Currently, there is already an industrial production of HP (TPT) and solar collectors (SC) based on them [8]. In the SC HP and TPT, they provide simplification of the collection of structures, high modularity, maintainability and reliability. Apply SC to heat water of active or passive type. An active system uses an electric pump to circulate fluid through a manifold. The passive system does not have a pump and uses only natural circulation. SC with HP or TPT are structurally similar to execution.
HPs (TPTs) are fixed on the heat-receiving panel by the evaporation zone, and the condensation zones are located in the storage tank. Differences exist only in the designs of absorbing panels, areas of condensation zones and heat transfer fluids HP (TPT). The authors of the studies [9, 10] developed and created SCs based on aluminum profile HPs with axial grooves of a $\Omega$-shape, operating in the two-phase thermosiphon mode. The collector panel, which absorbs the heat of sunlight, consists of aluminum HPs made of a flat aluminum profile. Heat is perceived by the flat surface of the HP evaporation zone and is transferred to a liquid heat exchanger located on their condensation zones. Such a heat transfer system provides low hydraulic resistance of the solar collector heat exchanger and, accordingly, low energy consumption for pump operation. The disadvantage of this SC is that it has heat losses during the transfer of radiation heat transfer in the long wavelength range between the absorbing flat panel and the heat pipe.

The authors of this work propose a technical solution to the above drawback by creating a new panel that absorbs 
sunlight. The cross-section of a full-scale collector with a new absorbing panel is shown in Fig. 1.

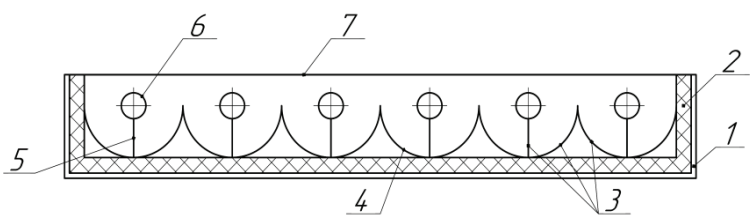

Fig. 1. The cross section of the solar collector (SC)

1 - 5C case; 2 - thermal insulation; 3 - absorber; 4 - cylindrical segment; 5 - edge; 6 - heat pipe; 7 - glass cover
- copper-constantan thermocouples with a wire diameter of $0.15 \mathrm{~mm}$ for measuring the temperature field of the absorbing panel, the temperature of the external wall of the HP, the temperature at the inlet and outlet of the heat exchanger;

- analog input module;

- signal adapter;

- personal computer;

- FEP-4 pyrometer for measuring the magnitude of the radiation flux of solar radiation incident on the experimental site.

In order not to create a full-scale new SC according to Fig. 1, it is proposed to manufacture an SC element of a special profile.

The element of the specially profiled absorbing panel is made in the form of a cylindrical surface, in the lower inner part of which there is a rib, at the free end of which there is a zone of evaporation of the HP.

The cylindrical surface of the panel plays the role of a concentrator of the reflected part of the radiation and the panel's own radiation in the region of the heat pipe [11].

To conduct a performance analysis of the new SC based on aluminum structural HP with a cylindrical absorbing panel, two SC layouts are created - with a flat absorbing panel and a cylindrical absorbing panel.

Thus, the object of research is the thermal efficiency of solar collectors based on aluminum structural HPs. And the aim of this research is to develop the design of the SC element, on the basis of which it is possible to increase the efficiency of the SC due to the implementation of additional radiation heat transfer in the long wavelength range between the absorbing panel and the heat pipe with a coolant.

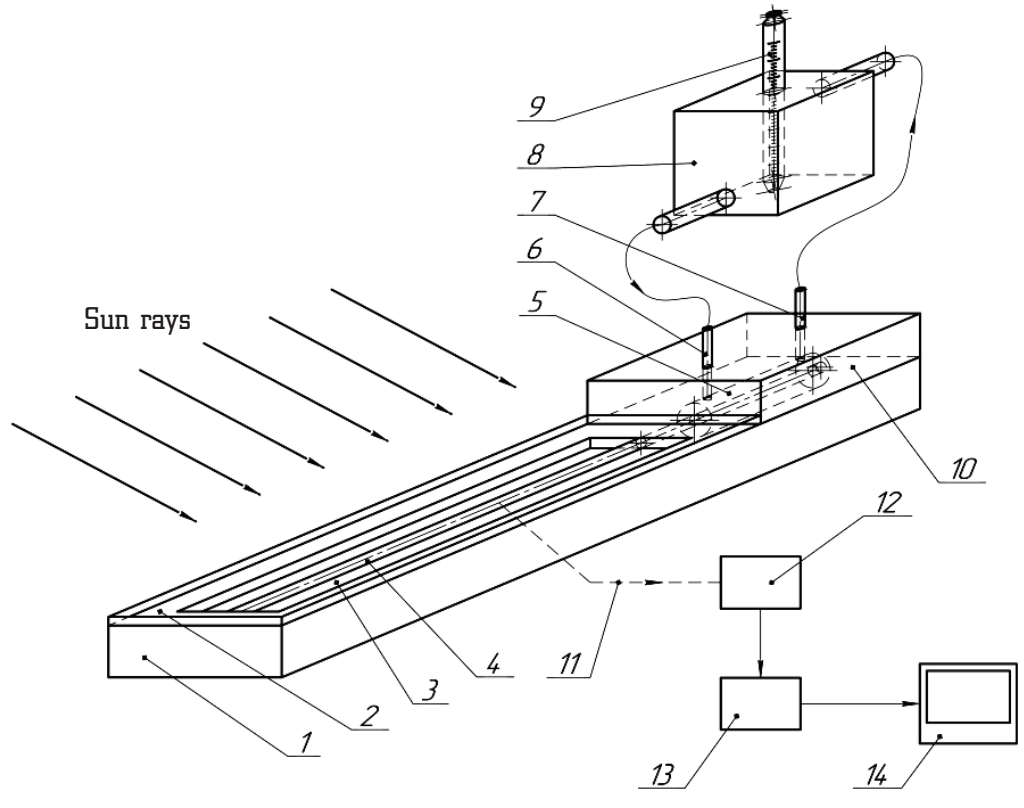

Fig. 2. Solar water heater:

1 - sealed case; 2 - glass cover; 3 - heat-absorbing panel of the solar collector element; 4 - heat pipe; 5 - pipe-in-pipe heat exchanger; 6 - input coolant; 7 - coolant outlet; 8 - heat storage tank; 9 - thermometer; 10 - heat-insulating cover; 11 - copper-constantan thermocouples; 12 - analog input module; 13 - signal adapter; 14 - personal computer

\section{Methods of research}

For research, the authors develop and create two experimental facilities in accordance with [12]. Fig. 2 shows the design of a solar water heater, made of a highly efficient element heat-absorbing aluminum panel and one aluminum structural HP. HP is fixed on the panel with an evaporation zone, and the condensation zone is placed in a «pipe in pipe» type liquid heat exchanger, which is connected to the heat storage tank. Pentane is used as the heat carrier of aluminum heat pipes.

The study of SC elements based on aluminum structural HPs mounted on a flat (Fig. 3, a) and cylindrical (Fig. 3, b) absorbing panels is carried out using sunlight in the summer. The heat flux of sunlight was determined by the FEP-4 pyrometer (Russia).

A 3D model of the SC structure based on aluminum structural HP, which is mounted on a cylindrical aluminum absorption panel, is shown in Fig. 4.

The experimental installations of solar water heaters (SWH) include the following measuring instruments:

- mercury thermometer with a division value of $0.1^{\circ} \mathrm{C}$ to determine the temperature of the water in the storage tank of the solar heater;

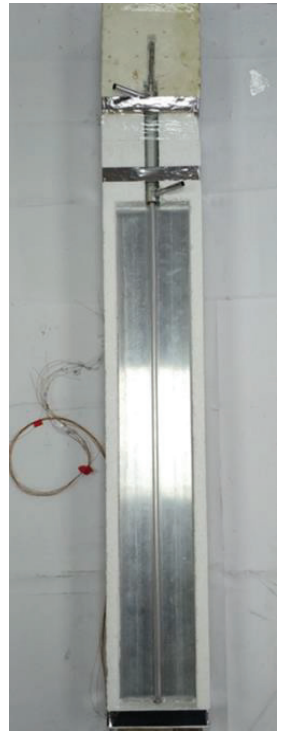

a

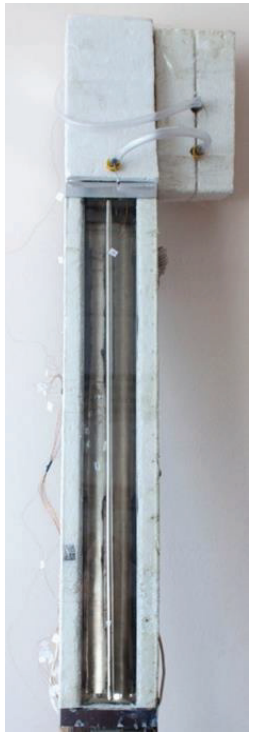

$b$
Fig. 3. An element of the solar collector based on an aluminum structural heat pipe, which is mounted on an aluminum heat-absorbing panel: $a$ - flat; $b$ - cylindrical 


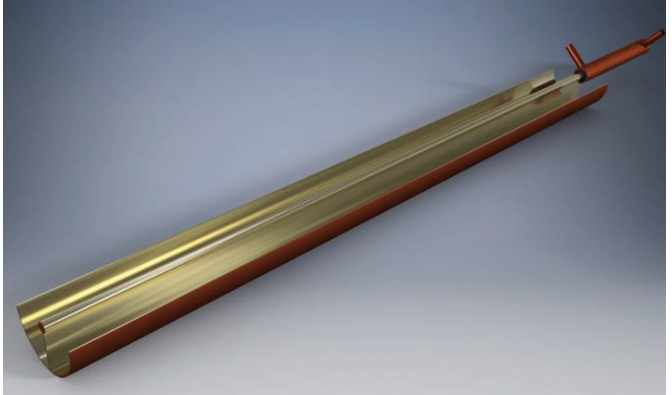

Fig. 4. 3D model of a solar collector design based on an aluminum structural heat pipe mounted on a cylindrical aluminum panel

The geometric characteristics of aluminum structural HPs mounted on aluminum flat and cylindrical heatabsorbing panels (Fig. 5):

- outer diameter $D_{0}=10 \mathrm{~mm}$;

- inner diameter $d_{i 1}=5 \mathrm{~mm}$;

- inner diameter $d_{i 2}=8 \mathrm{~mm}$;

- length $l=1000 \mathrm{~mm}$;

- the number of axial $\Omega$-shaped grooves - 14 pcs.

The geometric characteristics of a flat absorber with aluminum alloy AD31:

- length $l=810 \mathrm{~mm}$;

- width $b=120 \mathrm{~mm}$;

- thickness $S=1.2 \mathrm{~mm}$.

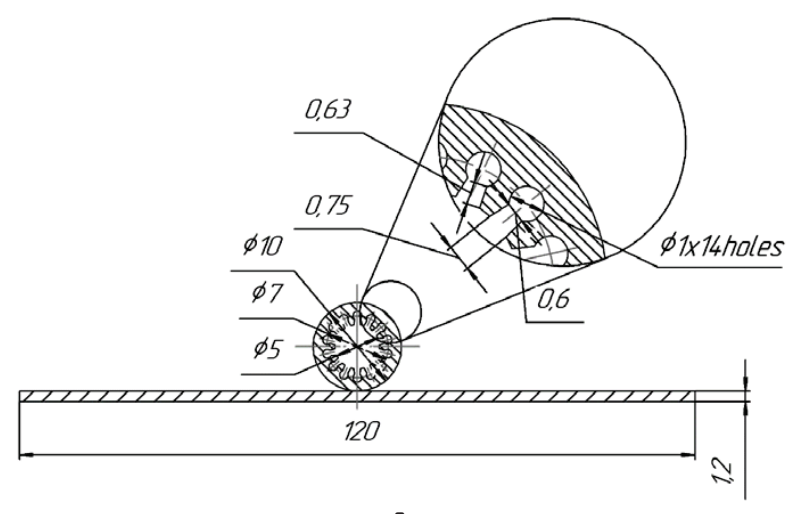

$a$

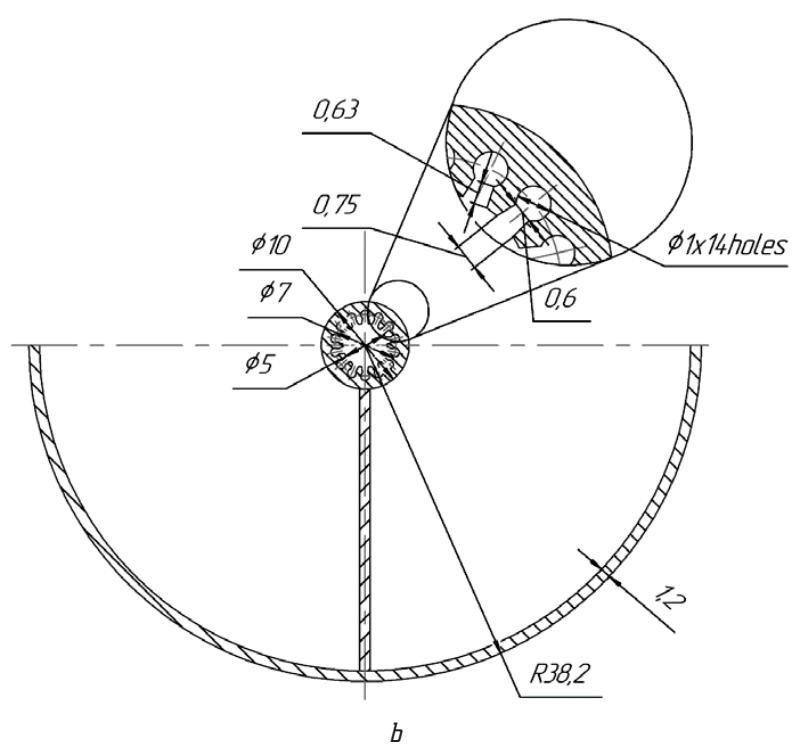

Fig. 5. The cross section of the experimental plot with an absorbing panel: $a$ - flat; $b$ - cylindrical
The geometric characteristics of a cylindrical absorber with aluminum alloy AD31:

- length $l=810 \mathrm{~mm}$;

- radius of the cylindrical surface $R=38.2 \mathrm{~mm}$;

- thickness $S=1.2 \mathrm{~mm}$.

The amount of thermal energy absorbed by water in the SWH is determined by the formula:

$$
Q=c_{w} \cdot M_{w}\left(t_{w 1}-t_{w 2}\right), \mathrm{J},
$$

where $c_{w}$ - heat capacity of water, $\mathrm{J} /(\mathrm{kg} \mathrm{K}) ; M_{w}$ - amount of heated water, $\mathrm{kg} ; t_{w 1}$ - average water temperature in the storage tank, ${ }^{\circ} \mathrm{C} ; t_{w 2}$ - preliminary average water temperature in the storage tank, ${ }^{\circ} \mathrm{C}$.

The value of the specific heat flux, perceived heat-absorbing floor of solar collectors, is determined by the formula:

$$
q=\frac{Q}{F \cdot \tau}, \mathrm{W} / \mathrm{m}^{2},
$$

where $F$ - the area of heat-absorbing surfaces of a flat or cylindrical collector, $\mathrm{m}^{2} ; \tau-\mathrm{SWH}$ operating time between measurements of water temperatures in the storage tank, ${ }^{\circ} \mathrm{C}$.

The areas of heat-absorbing surfaces of a flat and cylindrical SC are equal.

The SWH efficiency coefficients are calculated as the ratio of the specific heat flux $q$ to the incident radiation flux infrared created by the sun $E \approx 850 \mathrm{~W} / \mathrm{m}^{2}$ :

$$
\eta=\frac{q}{E}
$$

To compare various types of SC structures, a characteristic of their effectiveness is used - a coefficient of performance depending on:

$$
X=\left(t_{w}-t_{a}\right) / E, \mathrm{~K} \cdot \mathrm{m}^{2} / \mathrm{W},
$$

where $t_{w}$ - the average temperature of the water in the storage tank, ${ }^{\circ} \mathrm{C} ; t_{a}$ - average air temperature, ${ }^{\circ} \mathrm{C}, E$ - solar radiation flux incident on $\mathrm{SC}, \mathrm{W} / \mathrm{m}^{2}$.

Parameter $X$ is a variable value of thermal resistances of this $\mathrm{SC}$ design.

\section{Research results and discussion}

The results of studies of flat SC are given in Table 1, and cylindrical - in Table 2 .

Symbols in the Tables 1, 2:

$t_{1}-$ HP temperature in the condensation zone, ${ }^{\circ} \mathrm{C}$;

$t_{2}$ - HP temperature in the evaporation zone, ${ }^{\circ} \mathrm{C}$;

$t_{3}$ - average temperature of the absorbing panel, ${ }^{\circ} \mathrm{C}$;

$t_{a}-$ ambient temperature, ${ }^{\circ} \mathrm{C}$;

$t_{t}$ - temperature of the heated water in the storage $\operatorname{tank},{ }^{\circ} \mathrm{C}$;

$\Delta t$ - increase in water temperature in the storage tank between measurements, ${ }^{\circ} \mathrm{C}$;

$\tau$ - measurement time, min;

$Q$ - amount of thermal energy absorbed by water through a heat exchanger at certain intervals of time, J;

$Q_{f}$ - magnitude of the heat flux, is perceived by the heat-absorbing surface of the SC, W;

$q$ - specific heat flux is perceived by the heat-absorbing surface of the $\mathrm{SC}, \mathrm{W} / \mathrm{m}^{2}$;

$\eta$ - coefficient of SC performance;

$X$ - variable value of thermal resistances. 
The results of experimental studies of a solar collector based on an aluminum heat pipe with a flat aluminum absorbing panel

\begin{tabular}{|c|c|c|c|c|c|c|c|c|c|c|c|c|}
\hline No. & $t_{1},{ }^{\circ}[$ & $t_{2,}{ }^{\circ} \mathrm{C}$ & $t_{3},{ }^{\circ} \mathrm{C}$ & $T_{a,}{ }^{\circ} \mathrm{C}$ & $T_{t,}{ }^{\circ} \mathrm{C}$ & $\Delta t,{ }^{\circ} \mathrm{C}$ & $\tau$, min & $\square, \mathrm{kJ}$ & $\square_{f}, \mathrm{~W}$ & $q, \mathrm{~W} / \mathrm{m}^{2}$ & Performance & $X \cdot 10^{3}, \mathrm{~K} \cdot \mathrm{m}^{2} / \mathrm{W}$ \\
\hline 1 & 46.8 & 51.5 & 49.2 & 42.1 & 43.6 & - & 0 & - & - & - & - & - \\
\hline 2 & 46.8 & 53.8 & 49.9 & 42.0 & 44.4 & 0.8 & 2 & 1.5 & 12.54 & 129.0 & 0.152 & 2.8 \\
\hline 3 & 48.0 & 56.1 & 50.7 & 42.4 & 45.4 & 1.0 & 4 & 1.9 & 15.68 & 159.9 & 0.188 & 4 \\
\hline 4 & 49.2 & 58.4 & 51.5 & 42.3 & 45.9 & 0.5 & 6 & 0.94 & 7.84 & 80.0 & 0.094 & 4.6 \\
\hline 5 & 49.2 & 58.4 & 51.5 & 42.1 & 46.7 & 0.8 & 8 & 1.5 & 12.54 & 128.0 & 0.151 & 5.5 \\
\hline 6 & 49.2 & 58.4 & 53.8 & 42.5 & 47.5 & 0.8 & 10 & 1.5 & 12.54 & 128.0 & 0.151 & 6.5 \\
\hline 7 & 51.5 & 60.0 & 53.8 & 43 & 48.4 & 0.9 & 12 & 1.7 & 14.11 & 144.0 & 0.169 & 7.5 \\
\hline 8 & 51.5 & 60.0 & 53.8 & 41.8 & 49.3 & 0.9 & 14 & 1.7 & 14.11 & 144.0 & 0.169 & 8.6 \\
\hline 9 & 51.5 & 60.0 & 55.4 & 42.3 & 50.0 & 0.7 & 16 & 1.3 & 10.97 & 112.0 & 0.132 & 9.4 \\
\hline 10 & 52.7 & 60.0 & 56.1 & 42.0 & 50.8 & 0.8 & 18 & 1.5 & 12.54 & 128.0 & 0.151 & 10.4 \\
\hline 11 & 53.8 & 60.0 & 56.1 & 41.9 & 51.5 & 0.7 & 20 & 1.3 & 10.97 & 112.0 & 0.132 & 11.2 \\
\hline 12 & 52.5 & 60.0 & 54.6 & 42.6 & 52.0 & 0.5 & 22 & 0.94 & 7.84 & 80.0 & 0.094 & 11.8 \\
\hline 13 & 53.8 & 60.0 & 56.1 & 42.0 & 52.8 & 0.8 & 24 & 1.5 & 12.54 & 128.0 & 0.151 & 12.7 \\
\hline 14 & 53.8 & 60.0 & 58.4 & 42.6 & 53.4 & 0.6 & 26 & 1.1 & 9.41 & 96.0 & 0.113 & 13.4 \\
\hline 15 & 56.1 & 60.0 & 58.4 & 43.0 & 54.0 & 0.6 & 28 & 1.1 & 9.41 & 96.0 & 0.113 & 14.1 \\
\hline 16 & 56.1 & 60.7 & 58.4 & 41.8 & 54.6 & 0.6 & 30 & 1.1 & 9.41 & 96.0 & 0.113 & 14.8 \\
\hline 17 & 56.1 & 60.7 & 58.8 & 42.5 & 55.7 & 1.1 & 34 & 2.1 & 8.62 & 88.0 & 0.103 & 16.1 \\
\hline 18 & 56.6 & 63.0 & 60.7 & 42.7 & 56.4 & 0.7 & 38 & 1.3 & 5.49 & 56.0 & 0.066 & 16.9 \\
\hline 19 & 58.4 & 63.0 & 60.7 & 42.2 & 57.2 & 0.8 & 42 & 1.5 & 6.27 & 64.0 & 0.075 & 17.9 \\
\hline 20 & 58.4 & 65.4 & 60.7 & 41.0 & 58.3 & 1.1 & 46 & 2.1 & 8.62 & 88.0 & 0.103 & 19.2 \\
\hline 21 & 59.6 & 66.5 & 63.0 & 42.6 & 59.6 & 1.3 & 54 & 2.4 & 5.09 & 52.0 & 0.061 & 20.7 \\
\hline 22 & 61.7 & 66.5 & 63.7 & 42.8 & 61.0 & 1.4 & 64 & 2.6 & 4.39 & \begin{tabular}{ll|}
44.8 \\
\end{tabular} & 0.053 & 22.4 \\
\hline 23 & 63.7 & 67.5 & 63.8 & 42.6 & 63.0 & 2.0 & 72 & 3.8 & 3.92 & 40.0 & 0.047 & 24.7 \\
\hline 24 & 64.7 & 67.5 & $\begin{array}{l}64.8 \\
\end{array}$ & 41.7 & 64.0 & 1.0 & 80 & 1.9 & 3.92 & 40.0 & 0.047 & 25.9 \\
\hline 25 & 64.8 & 67.5 & 65.8 & 42.0 & 64.6 & 0.6 & 88 & 1.1 & 2.35 & 24.0 & 0.028 & 26.6 \\
\hline 26 & 65.5 & 67.5 & 65.8 & 43.2 & 65.2 & 0.6 & 96 & 1.1 & 2.35 & 24.0 & 0.028 & 27.3 \\
\hline 27 & 65.5 & 68.8 & 66.5 & 42.6 & 65.2 & 0.1 & 104 & 1.9 & 0.39 & 4.0 & 0.005 & 27.4 \\
\hline
\end{tabular}

The results of experimental studies of a solar collector based on an aluminum heat pipe with a cylindrical aluminum absorbing panel

Table 2

\begin{tabular}{|c|c|c|c|c|c|c|c|c|c|c|c|c|}
\hline No. & $t_{1},{ }^{\circ} \mathrm{C}$ & $t_{2},{ }^{\circ} \mathrm{C}$ & $t_{3,}{ }^{\circ} \mathrm{C}$ & $T_{a,}{ }^{\circ} \mathrm{C}$ & $T_{t,}{ }^{\circ} \mathrm{C}$ & $\Delta t,{ }^{\circ} \mathrm{C}$ & $\overline{\tau, \min }$ & $\overline{Q, \mathrm{~kJ}}$ & $\overline{Q_{f,} \mathrm{~W}}$ & $q_{1} \mathrm{~W} / \mathrm{m}^{2}$ & Performance & $X \cdot 10^{3}, \mathrm{~K} \cdot \mathrm{m}^{2} / \mathrm{W}$ \\
\hline 1 & 45.2 & 56.4 & 49.3 & 42.1 & 43.6 & - & 0 & - & - & - & - & - \\
\hline 2 & 46.3 & 59.1 & 51.3 & 42.0 & 44.8 & 1.2 & 2 & 2.3 & 18.81 & 193.5 & 0.228 & 3.3 \\
\hline 3 & 47.5 & 61.0 & 53.4 & 42.4 & 45.8 & 1.0 & 4 & 1.9 & 15.68 & 161.3 & 0.190 & 4.5 \\
\hline 4 & 48.9 & 61.6 & 54.3 & 42.3 & 46.7 & 0.9 & 6 & 1.7 & 14.11 & 145.1 & 0.171 & 5.5 \\
\hline 5 & 49.6 & 63.0 & 56.3 & 42.1 & 47.8 & 1.1 & 8 & 2.1 & 17.24 & 177.4 & 0.209 & 6.8 \\
\hline 6 & 51.3 & 64.4 & 56.5 & 42.5 & 48.5 & 0.7 & 10 & 1.3 & 10.97 & 112.9 & 0.133 & 7.6 \\
\hline 7 & 51.7 & 64.2 & 57.1 & 43 & 49.5 & 1.0 & 12 & 1.9 & 15.68 & 161.3 & 0.190 & 8.8 \\
\hline 8 & 52.0 & 67.5 & 58.3 & 41.8 & 50.5 & 1.0 & 14 & 1.9 & 15.68 & 161.3 & 0.190 & 10.0 \\
\hline 9 & 52.9 & 64.6 & 58.9 & 42.3 & 51.5 & 1.0 & 16 & 1.9 & 15.68 & 161.3 & 0.190 & 11.2 \\
\hline 10 & 52.9 & 64.8 & 58.0 & 42.0 & 52.3 & 0.8 & 18 & 1.5 & 12.54 & 129.0 & 0.152 & 12.1 \\
\hline 11 & 53.8 & 65.1 & 58.9 & 41.9 & 53.1 & 0.8 & 20 & 1.5 & 12.54 & 129.0 & 0.152 & 13.1 \\
\hline 12 & 58.4 & 66.0 & 60.0 & 42.6 & 54.0 & 0.9 & 22 & 1.7 & 14.11 & 145.1 & 0.171 & 14.1 \\
\hline 13 & 55.2 & 64.8 & 59.7 & 42.0 & 54.5 & 0.5 & 24 & 0.9 & 7.84 & 80.6 & 0.095 & 14.7 \\
\hline 14 & 55.9 & 65.3 & 60.6 & 42.6 & 55.1 & 0.6 & 26 & 1.1 & 9.41 & 96.8 & 0.114 & 15.4 \\
\hline 15 & 56.6 & 65.5 & 61.1 & 43.0 & 55.8 & 0.7 & 28 & 1.3 & 10.97 & 112.9 & 0.133 & 16.2 \\
\hline 16 & 57.3 & 67.3 & 62.3 & 41.8 & 56.3 & 0.5 & 30 & 0.9 & 7.84 & 80.6 & 0.095 & 16.8 \\
\hline 17 & 58.4 & 67.5 & 63.2 & 42.5 & 57.1 & 0.8 & 34 & 1.5 & 6.27 & 64.5 & 0.076 & 17.8 \\
\hline 18 & 58.9 & 68.7 & 64.1 & 42.7 & 58.2 & 1.1 & 38 & 2.1 & 8.62 & 88.7 & 0.104 & 19.1 \\
\hline 19 & 60.5 & 69.8 & 64.5 & 42.2 & 58.9 & 0.7 & 42 & 1.3 & 5.49 & 56.4 & 0.066 & 19.9 \\
\hline 20 & 61.4 & 69.1 & 66.1 & 41.0 & 59.9 & 1.0 & 46 & 1.9 & 7.84 & 80.6 & 0.095 & 21.1 \\
\hline 21 & 62.6 & 68.9 & 66.6 & 42.6 & 61.0 & 1.1 & 54 & 2.1 & 4.31 & 44.3 & 0.052 & 22.4 \\
\hline 22 & 63.5 & 70.7 & 67.9 & 42.8 & 62.3 & 1.3 & 64 & 2.4 & 4.08 & 41.9 & 0.049 & 23.9 \\
\hline 23 & 64.2 & 69.1 & 67.5 & 42.6 & 63.5 & 1.2 & 72 & 2.3 & 4.7 & 48.4 & 0.057 & 25.3 \\
\hline 24 & 65.1 & 70.7 & 69.4 & 41.7 & 65.0 & 1.5 & 80 & 2.8 & 5.88 & 60.5 & 0.071 & 27.1 \\
\hline 25 & 65.3 & 70.9 & 69.1 & 42.0 & 65.2 & 0.2 & 88 & 0.4 & 0.78 & 8.1 & 0.009 & 27.3 \\
\hline 26 & 66.4 & 72.0 & 71.7 & 43.2 & 66.0 & 0.8 & 96 & 1.5 & 3.13 & 32.3 & 0.038 & 28.2 \\
\hline 27 & 66.6 & 70.7 & 69.8 & 42.6 & 66.2 & 0.2 & 104 & 0.4 & 0.78 & 8.1 & 0.009 & 28.5 \\
\hline
\end{tabular}


The performance graphs of SC elements based on an aluminum structural HP mounted on a flat or cylindrical aluminum heat-absorbing panel are shown in Fig. 6, and the time dependence of the increase in water temperature in the heat storage tank is shown in Fig. 7.

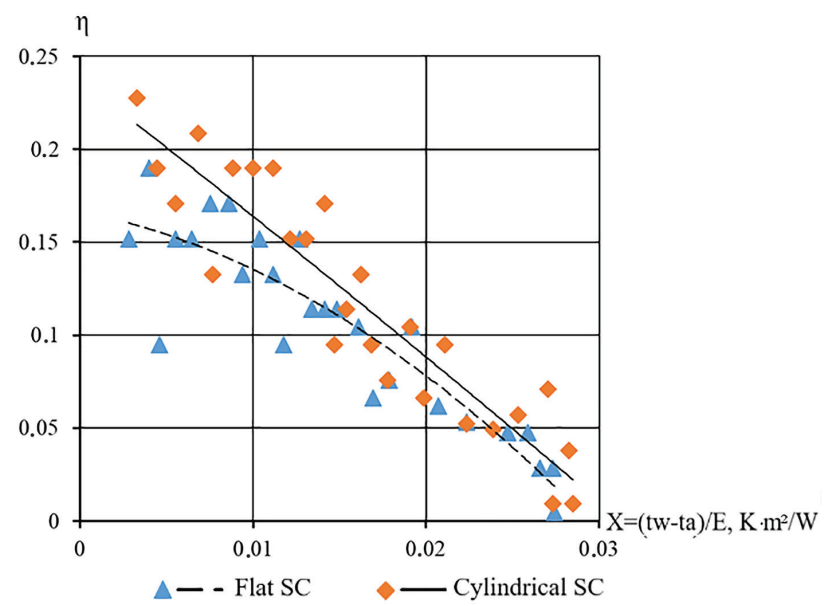

Fig. 6. Dependences of the current values of the efficiency on the parameter $X$ for an aluminum flat and cylindrical collector $\Delta \mathrm{t},{ }^{\circ} \mathrm{C}$

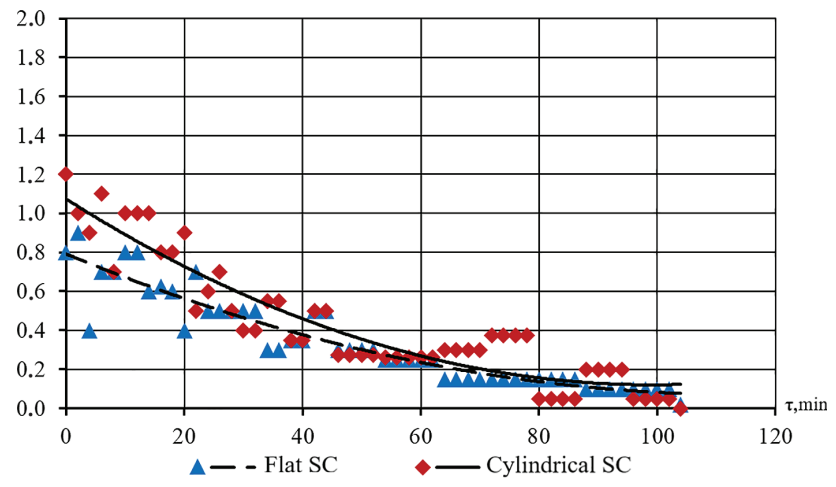

Fig. 7. Dependences of the increase in water temperature in the heat storage tank on time for an aluminum flat and cylindrical collector

Fig. 6 shows that the current SC efficiency based on an aluminum structural heat pipe with a cylindrical absorbing panel in the initial period of heating water is up to $6 \%$ more than in a solar collector with a flat absorbing panel, and at the end of heating up to $1.5 \%$.

During research, the average air temperature was $42.3^{\circ} \mathrm{C}$. The initial temperature of the water in the storage tanks was $43.6{ }^{\circ} \mathrm{C}$. The final temperature of the water in the SWH storage tank with SC based on aluminum HP mounted on a flat aluminum panel was $65.2^{\circ} \mathrm{C}$. The final temperature of the water in the SWH storage tank with SC based on aluminum HP, which is mounted on a cylindrical aluminum panel, was $66.2^{\circ} \mathrm{C}$.

\section{Conclusions}

A new design of the solar collector element is developed and investigated, on the basis of which it is possible to increase the thermal efficiency of the solar collector based on aluminum structural heat pipes. It is shown that the thermal efficiency of a new solar collector based on an aluminum structural heat pipe with a cylindrical absorbing panel in the initial period of heating water is up to $6 \%$ more than in a solar collector with a flat absorbing panel, and at the end of heating up to $1.5 \%$.

The research results of solar collectors based on aluminum structural heat pipes will be useful in the development of new designs of solar collectors.

\section{References}

1. Bezrodny, M. K., Pioro, I. L., Kostyuk, T. O. (2005). Transfer Processes in Two-phase Thermosyphone Systems. Theory and Practice. Kyiv: Augmented and Revised Edition. Fact, 704.

2. Peterson, G. P. (1994). An Introduction to Heat Pipes: modelling, testing and application. Wiley, 356.

3. Gaugler, R. S. (1966). Pat. No. 3229759 US. Evaporation condensation heat transfer devise. Declareted: 02.12.1963; published: 18.01 .1966$.

4. Reay, D. A., Kew, P. A. (2006). Heat Pipes. Fifth Edition, 374

5. Semena, M. G., Gershuni, A. N., Zaripov, V. K. (1984). Teplovye truby s metallovoloknistymi kapilliarnymi strukturami. Kyiv: Vischa shkola, 214

6. Singh, R., Mochizuki, M., Nguyen, T., Akbarzadeh, A. (2011) Application of heat pipes in energy conservation and renewable energy-based systems. Frontiers in Heat Pipes, 2, 033003, 1-13.

7. Vasiliev, L. L. (1988). Heat pipes in the systems with renewable energy sources. Science and technology. Minsk, 7-35.

8. Walker, A., Mahjouri, F., Stieler, R. (2004). Evacuated-Tube Heat-Pipe Solar Collectors Applied to the Recirculation Loop in a Federal Building. NREL Report, No. CP-710-36149, 9.

9. Rassamakin, B. M., KHairnasov, S. M., Zaripov, V. K. (2012). Razrabotka i issledovanie teplovykh trub novogo profilia dlia solnechnykh kollektorov s ispolzovaniem selektivnogo pokrytiia pogloschaiuschei poverkhnosti. Otchet po NIR. KPI im. Igoria Sikorskogo 2434 - p; Nomer gosregistracii temy - 0111U000567. Kyiv.

10. Khairnasov, S. M. (2010). Eksperimentalnoe issledovanie effektivnogo ploskogo solnechnogo kollektora na teplovykh trubakh. Vozobnovliaemaia energiia, 2 (21), 35-39.

11. Marinenko, V. I. (2017). Pat. No. 118736 UA. Element soniachnogo kolektora. MPK F24J 2/04. No. u 201701760; declareted: 04.02.2017; published: 28.08.2017, Biul. No. 16 .

12. Marinenko, V. I. (2018). Pat. No. 123808 UA. Soniachnii pidigrivach vody. MPK: F24C 15/00. No. u 201709169; declareted: 18.09.2017; published: 12.03.2018, Bul. No. 5

Marinenko Vladimir, PhD, Associate Professor, Department of Nuclear Power Stations and Engineering Thermophysics, National Technical University of Ukraine «Igor Sikorsky Kyiv Polytechnic Institute»,Ukraine, e-mail: v.marinenko@gmail.com, ORCID: http:// orcid.org/0000-0002-8789-3432

Kulynych Vladyslav, Postgraduate Student, Department of Nuclear Power Stations and Engineering Thermophysics, National Technical University of Ukraine «Igor Sikorsky Kyiv Polytechnic Institute», Ukraine, e-mail: kulinichvladislav.2@gmail.com, ORCID: http:// orcid.org/0000-0002-5934-6423 